\title{
Synthesis of 5-methyl-5H-pyrrolo[2,3-c]quinoline and 4-methyl-4H-pyrrolo[2,3-c]isoquinoline: two new unnatural D-ring stripped isomers of the cryptolepine series
}

\author{
Gitte Van Baelen, Guy L. F. Lemière, Roger A. Dommisse, and Bert U. W. Maes* \\ Department of Chemistry, University of Antwerp, Groenenborgerlaan 171, B-2020 Antwerp, \\ Belgium \\ E-mail:bert.maes@ua.ac.be
}

Dedicated to Prof. Henk van der Plas on the occasion of his $80^{\text {th }}$ birthday

\begin{abstract}
5-Methyl-5H-pyrrolo[2,3-c]quinoline and 4-methyl-4H-pyrrolo[2,3-c]isoquinoline have been synthesized via a domino condensation - Heck cyclisation of, respectively, 4-bromoquinolin-3amine or 4-bromoisoquinolin-3-amine and acetaldehyde. Selective methylation of the tricyclic skeletons yielded the title compounds 5-methyl-5H-pyrrolo[2,3-c]quinoline and 4-methyl-4Hpyrrolo[2,3-c]isoquinoline.
\end{abstract}

Keywords: Malaria, Plasmodium falciparum, cryptolepines, palladium, annulation, aldehyde

\section{Introduction}

Malaria is an infectious disease caused by protozoa of the genus Plasmodium and transmitted by the Anopheles mosquito. Among the four pathogenic species, Plasmodium falciparum is the most dangerous one. Although this disease can be prevented and treated, it still kills more than one million people each year. ${ }^{1}$ A major problem is the increasing resistance of the parasite against the currently available drugs, hence the continuous need for new and more effective antiplasmodial drugs.

Within the scope of the battle against malaria, several alkaloids have been isolated from Cryptolepis sanguinolenta, a plant used in Central and West African traditional folk medicine to treat fevers caused by malaria. Among these isolated alkaloids are cryptolepine ${ }^{2 a}$ (5-methyl-5Hindolo[3,2-b]quinoline) (1), neocryptolepine ${ }^{2 b, 2 c} \quad$ (cryptotackieine, 5-methyl-5H-indolo[2,3$b]$ quinoline) (2) and isocryptolepine ${ }^{2 \mathrm{~d}, 2 \mathrm{e}} \quad$ (cryptosanguinolentine, 5-methyl-5H-indolo[3,2c]quinoline) (3) (Fig. 1). The benzo- $\beta$-carboline (5-methyl-5H-indolo[2,3-c]quinoline, for which we have adopted the name isoneocryptolepine) (4), surprisingly has not yet been found in nature. 
Recently, we developed an efficient Pd-catalyzed synthetic strategy for this "missing" alkaloid and its $7 H$-indolo[2,3-c] quinoline core. ${ }^{3,4}$

The alkaloids 1-4 are isomeric indoloquinolines which possess interesting antiplasmodial activities. The "missing" isomer isoneocryptolepine (4) has the best selectivity index (SI = cytotoxicity/antiplasmodial activity ratio) of the four indoloquinolines (Table 1). ${ }^{5}$
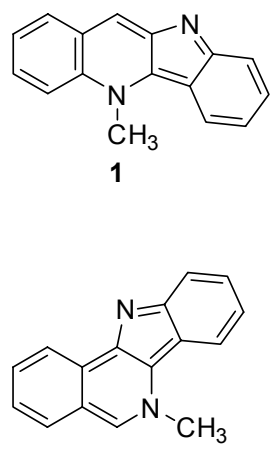

5

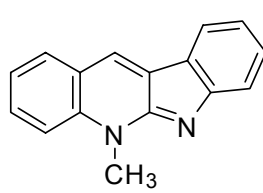

2<smiles>Cn1cc2ccccc2c2c3ccccc3nc1-2</smiles>

6

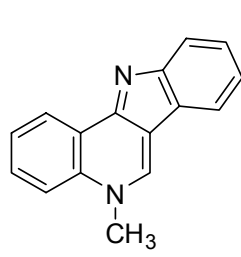

3<smiles>[Z]n1cc2nccc-2c2ccccc21</smiles>

8

Figure 1. Cryptolepine (1), neocryptolepine (2), isocryptolepine (3), isoneocryptolepine (4), 6methyl-6H-indolo[3,2-c] isoquinoline (5), 6-methyl-6H-indolo[2,3-c]isoquinoline (6) and target compounds 5-methyl-5H-pyrrolo[2,3-c]quinoline (7) and 4-methyl-4H-pyrrolo[2,3c]isoquinoline (8).

Table 1. Antiplasmodial activity $\left(\mathrm{IC}_{50}, \mu \mathrm{M}\right)$, cytotoxicity $\left(\mathrm{IC}_{50}, \mu \mathrm{M}\right)$ and selectivity index (cytotoxicity/antiplasmodial activity ratio) of compounds $1-4^{5}$ and 5-6 ${ }^{6}$

\begin{tabular}{cccc}
\hline Compound & $\begin{array}{c}\text { P. falciparum } \\
\mathrm{K} 1\end{array}$ & $\begin{array}{c}\text { Cytotoxicity } \\
(\mathrm{L} 6 \text { cells) }\end{array}$ & $\begin{array}{c}\text { Selectivity } \\
\text { Index }\end{array}$ \\
& $\mathrm{IC}_{50}(\mu \mathrm{M})$ & $\mathrm{IC}_{50}(\mu \mathrm{M})$ & \\
\hline $\mathbf{1}$ & $0.12 \pm 0.02$ & $1.12 \pm 0.07$ & 9.3 \\
$\mathbf{2}$ & $2.61 \pm 0.67$ & $3.24 \pm 0.04$ & 1.2 \\
$\mathbf{3}$ & $0.78 \pm 0.30$ & $1.19 \pm 0.26$ & 1.5 \\
$\mathbf{4}$ & $0.23 \pm 0.04$ & $4.32 \pm 0.04$ & 18.8 \\
$\mathbf{5}$ & $0.04 \pm 0.01$ & $1.31 \pm 0.85$ & 32.8 \\
$\mathbf{6}$ & $0.68 \pm 0.13$ & $1.48 \pm 0.72$ & 2.1 \\
\hline
\end{tabular}

The SI of 4 stimulated us to synthesise new unnatural indoloquinoline isomers. Recently, we described the synthesis and biological evaluation of the indoloisoquinolines 6-methyl-6Hindolo[3,2-c]isoquinoline (5) and 6-methyl-6H-indolo[2,3-c]isoquinoline (6), which are the isoquinoline analogues of respectively 3 and 4 (Fig. 1). ${ }^{6}$ Inspired by the initial results of the team 
of Quéguiner for cryptolepine ${ }^{7}$, we recently started exploring the effect of A and D-ring stripping on the SI in the cryptolepine series. ${ }^{8}$ In this article, we describe the synthesis of 5-methyl-5Hpyrrolo[2,3-c] quinoline (7) and 4-methyl-4H-pyrrolo[2,3-c]isoquinoline (8), D-ring debenzo analogues of respectively 4 and 6 (Fig. 1). A wide range of strategies can be used to synthesize azaindoles, e.g. Reissert, Madelung, Batcho-Leimgruber, Hemetsberger-Knittel and Bartoli synthesis. ${ }^{9}$ Besides these classical approaches, also strategies based on organometals have been used. ${ }^{9}$ The classical approaches are often lengthy procedures, require sometimes harsh reaction conditions and result often in poor yields. This, together with the previous work of our laboratory in the area of azaheteroaromatic scaffold construction via Pd catalysis, made us wonder whether the benzoazaindole core skeleton of $\mathbf{7}$ and $\mathbf{8}$ could be synthesized via a Pd-catalyzed annulation reaction. ${ }^{10}$ To the best of our knowledge these cores $(\mathbf{9}$ and $\mathbf{1 2})$ have not yet been reported.

\section{Results and Discussion}

In order to synthesize 3H-pyrrolo[2,3-c]quinoline (9) and 3H-pyrrolo[2,3-c]isoquinoline (12), the cores of $\mathbf{7}$ and $\mathbf{8}$, via a Pd-catalyzed annulation approach a halogenated quinoline and isoquinoline precursor were required (Scheme 1). Brominated compounds 4-bromoquinolin-3amine (10) and 4-bromoisoquinolin-3-amine (13) were chosen as precursors since the latter was already available in our lab. 13 was prepared via bromination of commercially available isoquinolin-3-amine (14) with NBS in methanol at room temperature. The reaction time could be diminished from 1 hour to 5 minutes by adding $0.1 \mathrm{~mol} \% \mathrm{NH}_{4} \mathrm{OAc}$ to the reaction and using $\mathrm{CH}_{3} \mathrm{CN}$ as the solvent (Scheme 2). ${ }^{6,11}$ This optimized bromination procedure also worked smoothly for the synthesis of 4-bromoquinolin-3-amine (10) starting from commercially available quinolin-3-amine (11) (Scheme 2).

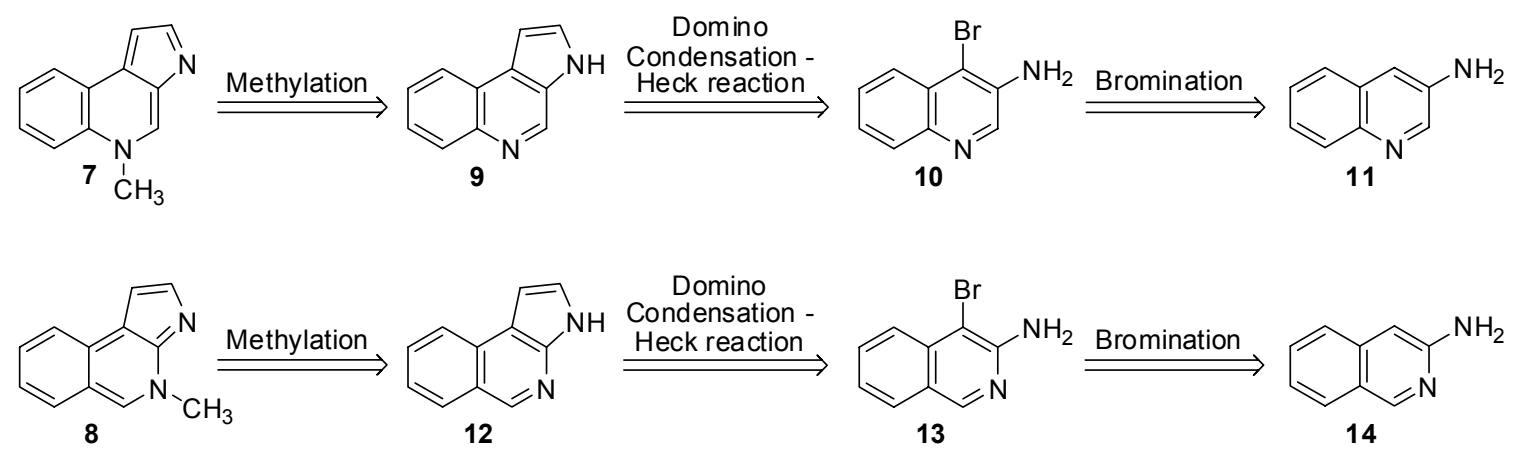

Scheme 1. Retrosynthetic analysis of target compounds 7 and $\mathbf{8}$. 


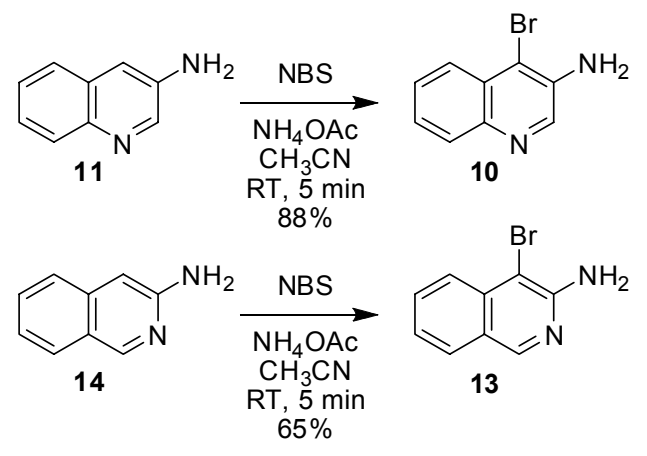

Scheme 2. Synthesis of 4-bromoquinolin-3-amine (10) and 4-bromoisoquinolin-3-amine (13) via bromination.

For the Pd-catalyzed annulation, the reaction conditions reported by Jia and Zhu were initially selected [ 1 equiv aldehyde, 3 equiv KOAc, 5 mol\% $\mathrm{Pd}(\mathrm{dba})_{2} / 10 \mathrm{~mol} \% \mathrm{X}-\mathrm{Phos}$, DMA, oil bath, $\left.120^{\circ} \mathrm{C}\right] .{ }^{10 a}$ These were developed for the synthesis of C-3 substituted indoles starting from ortho-bromoanilines or ortho-chloroanilines and aldehydes. DMA was substituted for DMF by us as the latter is readily commercially available as an extra dry solvent. Optimization of the reaction conditions, allowing the use of this low boiling and sensitive aldehyde, revealed that the use of a dehydrating agent as well as a higher amount of acetaldehyde significantly shortened the required reaction time. The effect of the excess of the aldehyde can be rationalized if one takes into account the ease of its trimerization and its very low boiling point. In both cases reagent is lost; in the former case via trimer formation (the reaction temperature of the annulation is 120 ${ }^{\circ} \mathrm{C}$ ), in the latter via evaporation (only a reflux condenser with standard water cooling was used). Therefore, the Pd-catalyzed annulations were always performed with a large excess $(5 \mathrm{~mL})$ of freshly distilled acetaldehyde to ensure there is enough monomeric acetaldehyde present for the initial condensation. Systematic lowering of the catalyst loading showed that the reaction could be driven to completion within 1 hour of stirring at $120{ }^{\circ} \mathrm{C}$ with a $2 \mathrm{~mol} \%$ catalyst loading. These optimized reaction conditions [5 $\mathrm{mL}(89 \mathrm{mmol})$ aldehyde, 3 equiv KOAc, $2 \mathrm{~mol} \% \mathrm{Pd}(\mathrm{dba})_{2} / 4$ mol\% X-Phos, DMF, oil bath, $120^{\circ} \mathrm{C}$ ] gave hitherto unknown $3 H$-pyrrolo[2,3-c]quinoline (9) in an excellent 98\% yield (Scheme 3). Similarly, 3H-pyrrolo[2,3-c]isoquinoline (12) could also be synthesised via this optimized procedure, but a catalyst loading of 1 mol\% nor 2 mol\% was sufficient to obtain full conversion in a reaction time of 1 hour. $10 \mathrm{~mol} \%$ was found to be able to drive the reaction to completion in 1 hour (Scheme 3). No catalyst loading between 2 and 10 mol\% was tested for substrate 13. Generally, lower loadings (e.g. $2 \mathrm{~mol} \%$ ) can be used if one takes into account a longer reaction time together with adding extra acetaldehyde in portions during the reaction. Presumably the decreased reactivity of $\mathbf{1 3}$ is due to the lower nucleophilicity of the amino group in comparison with $\mathbf{1 0}$ providing less enamine intermediate for the subsequent Heck cyclisation. 


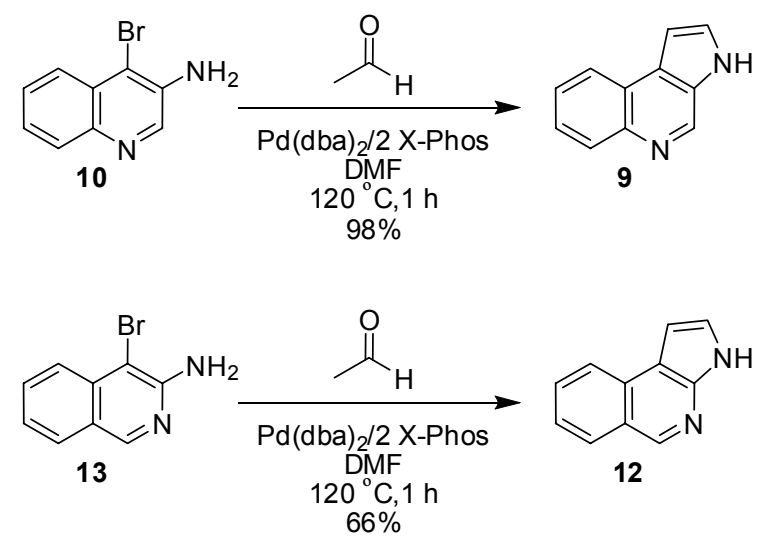

Scheme 3. Synthesis of 3H-pyrrolo[2,3-c]quinoline (9) and 3H-pyrrolo[2,3-c]isoquinoline (12) via a Pd-catalyzed annulation reaction.

Selective methylation of 9 and 12 at $N-5$ and $N-4$, respectively, was performed under our previously reported reaction conditions $\left(\mathrm{CH}_{3} \mathrm{I}\right.$, THF, reflux; then $28-30 \% \mathrm{NH}_{3}$ in $\left.\mathrm{H}_{2} \mathrm{O}\right)$ for the selective methylation of indoloquinolines (Scheme 4). ${ }^{4,6}$ Dimethylation can be avoided because the formed hydroiodide salts 7 .HI and 8. HI precipitate from the reaction mixture. A reaction time of 2 hours was necessary to obtain full conversion of 9 to 7 .HI and $\mathbf{1 2}$ to $\mathbf{8}$. HI. The free bases $\mathbf{7}$ and $\mathbf{8}$ can be easily obtained from 7 .HI and $\mathbf{8}$.HI in respectively $80 \%$ and 93\% yield after an acid-base extraction using ammonia in water (28-30\%).

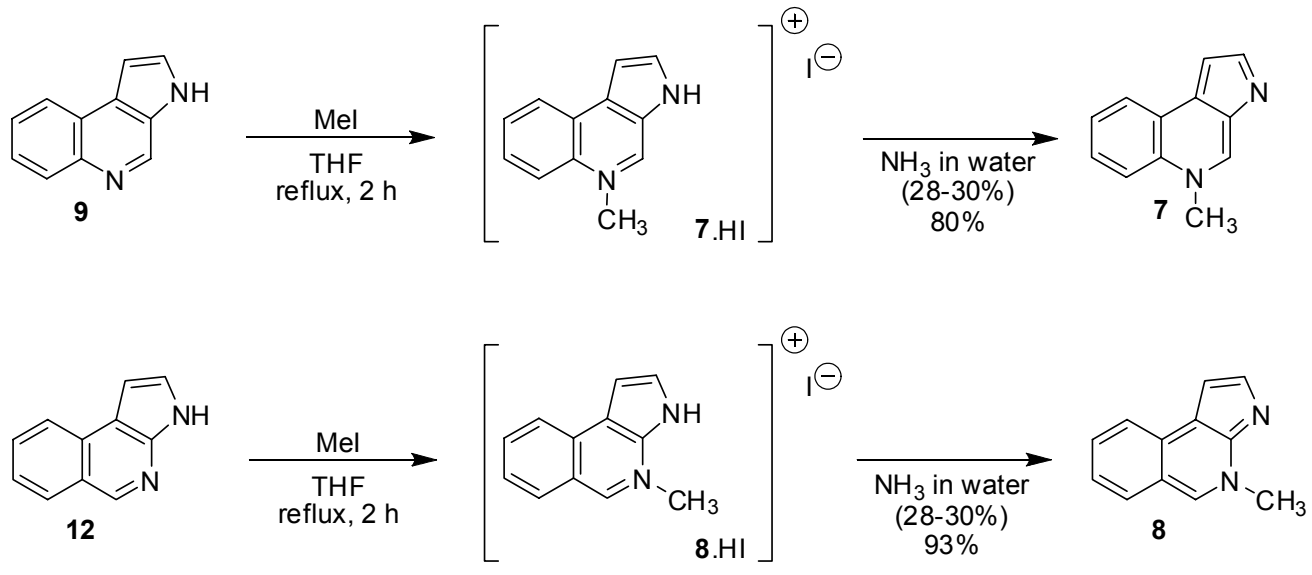

Scheme 4. Selective N-5 methylation of $\mathbf{9}$ and selective $N-4$ methylation of $\mathbf{1 2}$.

\section{Conclusions}

In conclusion, we synthesized two new unnatural isomers of the cryptolepine series: 5-methyl5H-pyrrolo[2,3-c] quinoline (7) and 4-methyl-4H-pyrrolo[2,3-c]isoquinoline (8). These 
compounds and their core skeletons have, to the best of our knowledge, never been synthesized before. 3H-Pyrrolo[2,3-c] quinoline (9) and 3H-pyrrolo[2,3-c]isoquinoline (12) were obtained via a Pd-catalyzed annulation, starting from respectively 4-bromoquinolin-3-amine (11) and 4bromoisoquinolin-3-amine (14). Interestingly, these represent the first examples of annulation of a pyrrole ring on a quinoline and isoquinoline via a domino condensation - Heck cyclisation. In addition, the use of acetaldehyde has not been reported so far. Selective methylation of the basic skeletons 9 and 12 yielded the target compounds 7 and 8 in respectively $69 \%$ and $40 \%$ overall yield.

\section{Experimental Section}

General Procedures. All melting points were determined on a Büchi apparatus and are uncorrected. The ${ }^{1} \mathrm{H}$ and ${ }^{13} \mathrm{C}$ NMR spectra were recorded on a Bruker spectrometer Avance 400 in the solvent indicated with TMS as an internal standard. All coupling constants are given in Hertz and chemical shifts are given in parts per million. The assignment of the ${ }^{1} \mathrm{H}$ NMR signals of all products is based on 2D NMR techniques (COSY, NOESY, HMQC and HMBC). For mass spectrometric analysis, samples were dissolved in $\mathrm{CH}_{3} \mathrm{OH}$ containing $0.1 \%$ formic acid and diluted to a concentration of approximately $10^{-5} \mathrm{~mol} / \mathrm{L}$. Injections $(10 \mu \mathrm{L})$ were directed to the mass spectrometer at a flow rate of $0.7 \mathrm{~mL} / \mathrm{min}\left(\mathrm{CH}_{3} \mathrm{OH}\right.$ and $0.1 \%$ formic acid), using a Kontron HPLC system. Mass spectrometric data were acquired on an AQA Navigator mass spectrometer (ThermoQuest, Finigan) equipped with an ApCI ionisation interface. The AQAMax voltage was set to $20 \mathrm{~V}$, the corona voltage to $3.5 \mathrm{kV}$ and the probe temperature to $250{ }^{\circ} \mathrm{C}$. Nitrogen gas was used for nebulation. Mass spectra were acquired by summing the spectra in the elution plug. In positive ion mode, the protonated molecule $[\mathrm{M}+\mathrm{H}]^{+}$was recorded. Accurate mass data were acquired on a Q-TOF 2 (Micromass) mass spectrometer equipped with a Nanomate (Advion, Ithaca, NY) nanoelectrospray source in LC-mode. Cone voltage (approx. $35 \mathrm{~V}$ ) and ESI voltage (approx. $1.7 \mathrm{kV}$ ) were optimized on one compound and used for all others. For the determination of the accurate mass of the molecular ion $[\mathrm{M}+\mathrm{H}]^{+}$, a solution of polyethylene glycol 300 in $\mathrm{CH}_{3} \mathrm{OH} / \mathrm{H}_{2} \mathrm{O}$ with $1 \mathrm{mmol}$ ammonium acetate, was added just before the mass spectrometer (at a rate of $1 \mu \mathrm{L} / \mathrm{min})$ to the mobile phase. The calculated masses of PEG ions $\left([\mathrm{M}+\mathrm{H}]^{+}\right.$and $\left[\mathrm{M}+\mathrm{NH}_{4}\right]^{+}$) were used as lock mass. Quinolin-3-amine, isoquinolin-3-amine, $\mathrm{CH}_{3} \mathrm{CN}$ (HPLC grade), DMF (99.85\%, water <50 ppm, extra dry over molecular sieve), THF (99.85\%, water $<50 \mathrm{ppm}$, extra dry over molecular sieve) and MeI were obtained from Acros. $\mathrm{Pd}(\mathrm{dba})_{2}$ and XPhos were obtained from Sigma-Aldrich. NBS, $\mathrm{NH}_{4} \mathrm{OAc}$ and paraldehyde were bought from Merck. NBS was recrystallized from water (10 g NBS in $100 \mathrm{~mL}$ water). Acetaldehyde was freshly depolymerized from paraldehyde (5 drops of $\mathrm{H}_{2} \mathrm{SO}_{4} / 10 \mathrm{~mL}$ paraldehyde) before use. Flash column chromatography was performed on Kieselgel 60 (ROCC, 0.040-0.063 mm). 
General bromination procedure. To a mixture of amine 11 or $14(0.865 \mathrm{~g}, 6.0 \mathrm{mmol})$ and $\mathrm{NH}_{4} \mathrm{OAc}(0.046 \mathrm{~g}, 0.6 \mathrm{mmol})$ in $\mathrm{CH}_{3} \mathrm{CN}(12 \mathrm{~mL})$ was added dropwise a solution of NBS (1.121 $\mathrm{g}, 6.3 \mathrm{mmol})$ in $\mathrm{CH}_{3} \mathrm{CN}(8 \mathrm{~mL})$. The reaction mixture was stirred at room temperature for $5 \mathrm{~min}$. The solvent was evaporated under reduced pressure and the reaction product was purified by recrystallization from water.

4-Bromoquinolin-3-amine (10). Yield 88\%; white to off-white powder; mp $140-142{ }^{\circ} \mathrm{C}$; $\delta_{\mathrm{H}}$ $\left(\mathrm{CDCl}_{3}\right): 8.48$ (s, 1H, H-2), 7.99-7.95 (m, 2H, H-5 and H-8), 7.55 (ddd, $J=8.2,6.9,1.3 \mathrm{~Hz}, 1 \mathrm{H}$, H-6 or H-7), 7.49 (ddd, $J=8.1,6.9,1.3 \mathrm{~Hz}, 1 \mathrm{H}, \mathrm{H}-6$ or H-7), 4.41 (br s, $\left.2 \mathrm{H}, \mathrm{NH}_{2}\right) ; \delta_{\mathrm{C}}\left(\mathrm{CDCl}_{3}\right)$ : $143.0,141.7,138.3,129.5,128.2,126.0,124.7,112.7$; $\delta_{\mathrm{C}}\left(\mathrm{DMSO}-d_{6}\right)$ : 143.2, 141.7, 141.1, 129.6, 128.6, 128.5, 125.2, 124.1, 108.6; HRMS (ESI) for $\mathrm{C}_{9} \mathrm{H}_{8} \mathrm{~N}_{2} \mathrm{Br}[\mathrm{M}+\mathrm{H}]^{+}$: calcd 222.9871, found 222.9874 .

4-Bromoisoquinolin-3-amine (13). Yield 65\%; pale yellow powder; mp 120-122 ${ }^{\circ} \mathrm{C}$ (lit. mp $\left.120-122{ }^{\circ} \mathrm{C}\right)^{6}$. The characterization data are identical to those previously reported by us in the literature. $^{6}$

General domino condensation-Heck cyclisation procedure. A round-bottomed flask was charged with $\mathrm{Pd}(\mathrm{dba})_{2}$ and X-Phos followed by dry DMF $(5 \mathrm{~mL})$. The mixture was flushed with $\mathrm{N}_{2}$ for $10 \mathrm{~min}$. Meanwhile, in another round bottomed flask 10 or 13 (0.446 g, $\left.2.0 \mathrm{mmol}\right)$, KOAc $(0.589 \mathrm{~g}, 6.0 \mathrm{mmol})$ and $\mathrm{MgSO}_{4}(0.3 \mathrm{~g})$ were weighed. To this mixture, the Pd-catalyst was added and the flask was flushed with $\mathrm{N}_{2}$ for $5 \mathrm{~min}$. Finally, freshly distilled acetaldehyde $(5 \mathrm{~mL}$, $89.0 \mathrm{mmol}$ ) was added. The resulting mixture was heated at $120^{\circ} \mathrm{C}$ for 1 hour under magnetic stirring. After cooling down the reaction to room temperature, EtOAc $(20 \mathrm{~mL})$ was added and the suspension was filtered over a pad of Celite ${ }^{\circledR}$ and rinsed with EtOAc $(20 \mathrm{~mL})$. Then EtOAc and DMF were removed under reduced pressure and the residue was purified by flash column chromatography on silica gel.

3H-Pyrrolo[2,3-c]quinoline (9). Pd(dba) 2 (0.023 g, $0.040 \mathrm{mmol})$, X-Phos (0.038 g, 0.080 mmol). Eluent: EtOAc/ $\mathrm{CH}_{2} \mathrm{Cl}_{2}$ (50/50); yield 98\%; pale yellow powder; mp 220-222 ${ }^{\circ} \mathrm{C}$; $\delta_{\mathrm{H}}$ (DMSO-d $)_{6}$ ) 11.98 (br s, 1H, NH), 9.03 (d, $J=0.6$ Hz, 1H, H-4), 8.31-8.25 (m, 1H, H-9), 8.06$8.00(\mathrm{~m}, 1 \mathrm{H}, \mathrm{H}-6), 7.65$ (t, $J=2.7 \mathrm{~Hz}, 1 \mathrm{H}, \mathrm{H}-2), 7.59-7.52(\mathrm{~m}, 2 \mathrm{H}, \mathrm{H}-7$ and H-8), 7.13 (ddd, $J=$ $2.7,1.9,0.9 \mathrm{~Hz}, 1 \mathrm{H}, \mathrm{H}-1)$; $\delta_{\mathrm{C}}\left(\mathrm{DMSO}-d_{6}\right): 142.4 ; 138.6 ; 129.7 ; 129.7 ; 128.1 ; 127.7 ; 126.1$; 125.8; 123.9; 123.7; 101.1; HRMS (ESI) for $\mathrm{C}_{11} \mathrm{H}_{9} \mathrm{~N}_{2}[\mathrm{M}+\mathrm{H}]^{+}$: calcd 169.0766, found 169.0768.

3H-Pyrrolo[2,3-c]isoquinoline (12). $\mathrm{Pd}(\mathrm{dba})_{2}(0.115 \mathrm{~g}, 0.200 \mathrm{mmol}), \mathrm{X}-\mathrm{Phos}(0.191 \mathrm{~g}, 0.400$ mmol). Eluent: $\mathrm{CH}_{2} \mathrm{Cl}_{2} /$ EtOAc (99/1), then $\mathrm{CH}_{2} \mathrm{Cl}_{2} /$ EtOAc (98/2); yield $66 \%$; yellow to brown powder; mp $142-144{ }^{\circ} \mathrm{C}$; $\delta_{\mathrm{H}}\left(\mathrm{DMSO}-d_{6}\right)$ : 11.96 (br s, $\left.1 \mathrm{H}, \mathrm{NH}\right), 8.90$ (s, 1H, H-5), 8.26 (br dd, $J=$ 8.2, $0.9 \mathrm{~Hz}, 1 \mathrm{H}, \mathrm{H}-9$ ), 8.12 (d, $J=8.1 \mathrm{~Hz}, 1 \mathrm{H}, \mathrm{H}-6), 7.75$ (ddd, $J=8.2,6.9,1.3 \mathrm{~Hz}, 1 \mathrm{H}, \mathrm{H}-8$ ), 7.50 (ddd, $J=8.1,6.9,1.3 \mathrm{~Hz}, 1 \mathrm{H}, \mathrm{H}-7), 7.46$ (t, $J=2.9 \mathrm{~Hz}, 1 \mathrm{H}, \mathrm{H}-2), 7.03$ (dd, $J=3.3,2.0 \mathrm{~Hz}$, $1 \mathrm{H}, \mathrm{H}-1) ; \delta_{\mathrm{C}}\left(\mathrm{DMSO}-d_{6}\right): 146.3,144.1,131.1,130.2,129.0,124.6,124.1,123.5,122.8,113.0$, 99.9; HRMS (ESI) for $\mathrm{C}_{11} \mathrm{H}_{9} \mathrm{~N}_{2}[\mathrm{M}+\mathrm{H}]^{+}$: calcd 169.0766, found 169.0768. 
General selective methylation procedure. In a round-bottomed flask pyrrolo(iso)quinoline (9 or 12) $(0.084 \mathrm{~g}, 0.5 \mathrm{mmol})$, dry THF $(7.5 \mathrm{~mL})$ and $\mathrm{CH}_{3} \mathrm{I}(3 \mathrm{~mL})$ were heated at reflux under $\mathrm{N}_{2}$ atmosphere (oil bath temperature: $80^{\circ} \mathrm{C}$ ) for 2 hours under magnetic stirring. Then the solvent was evaporated to dryness under reduced pressure and the crude product was mixed with silica and purified by flash column chromatography on silica gel using $\mathrm{CH}_{2} \mathrm{Cl}_{2} / \mathrm{MeOH}(90 / 10)$ as the eluent yielding pyrrolo(iso)quinoline hydroiodide (7.HI or 8.HI) as a yellow product. To obtain the free base, the salt was brought in a mixture of $\mathrm{CH}_{2} \mathrm{Cl}_{2}(100 \mathrm{~mL})$ and $28-30 \%$ ammonia in water $(100 \mathrm{~mL})$. The organic phase was separated and the aqueous phase was subsequently extracted with $\mathrm{CH}_{2} \mathrm{Cl}_{2}(4 \times 25 \mathrm{~mL})$. The combined organic phase was dried over $\mathrm{MgSO}_{4}$, filtered and evaporated to dryness.

5-Methyl-5H-pyrrolo[2,3-c]quinoline (7). Eluent system: $\mathrm{CH}_{2} \mathrm{Cl}_{2} / \mathrm{MeOH}$ (98/2), then $\mathrm{CH}_{2} \mathrm{Cl}_{2} / \mathrm{MeOH}(95 / 5)$; Yield $80 \%$; yellow to brown flakes; mp 176-178 ${ }^{\circ} \mathrm{C} ; \delta_{\mathrm{H}}\left(\mathrm{DMSO}-d_{6}\right): 8.99$ (s, 1H, H-4), 8.35 (br ddd, $J=7.1,2.0,0.9 \mathrm{~Hz}, 1 \mathrm{H}, \mathrm{H}-9$ ), 8.12 (d, $J=1.1 \mathrm{~Hz}, 1 \mathrm{H}, \mathrm{H}-2$ ), 8.00 (br ddd, $J=8.1,1.5,0.9 \mathrm{~Hz}, 1 \mathrm{H}, \mathrm{H}-6), 7.64$ (br ddd, $J=8.1,7.1,1.8 \mathrm{~Hz}, 1 \mathrm{H}, \mathrm{H}-7), 7.60$ (td, $J=7.1$, $1.3 \mathrm{~Hz}, 1 \mathrm{H}, \mathrm{H}-8), 7.15$ (br t, $J=1.0 \mathrm{~Hz}, 1 \mathrm{H}, \mathrm{H}-1), 4.28\left(\mathrm{~s}, 3 \mathrm{H}, \mathrm{CH}_{3}\right) ; \delta_{\mathrm{C}}\left(\mathrm{DMSO}-d_{6}\right): 152.3$, 138.7, 137.9, 133.9, 132.4, 126.8, 125.6, 125.2, 123.1, 118.0, 103.7, 42.8; HRMS (ESI) for $\mathrm{C}_{12} \mathrm{H}_{11} \mathrm{~N}_{2}[\mathrm{M}+\mathrm{H}]^{+}$: calcd 183.0922, found 183.0927 .

4-Methyl-4H-pyrrolo[2,3-c]isoquinoline (8). Eluent system: $\mathrm{CH}_{2} \mathrm{Cl}_{2} / \mathrm{MeOH}$ (90/10); Yield 93\%; yellow needles; mp $164-166^{\circ} \mathrm{C}$; $\delta_{\mathrm{H}}\left(\mathrm{DMSO}-d_{6}\right): 8.96(\mathrm{~s}, 1 \mathrm{H}, \mathrm{H}-5), 8.24$ (br dd, $J=8.5,0.9$ $\mathrm{Hz}, 1 \mathrm{H}, \mathrm{H}-9$ ), 8.10 (d, $J=8.4 \mathrm{~Hz}, 1 \mathrm{H}, \mathrm{H}-6), 7.76$ (ddd, $J=8.5,6.8,1.2 \mathrm{~Hz}, 1 \mathrm{H}, \mathrm{H}-8), 7.71$ (d, $J$ $=2.1 \mathrm{~Hz}, 1 \mathrm{H}, \mathrm{H}-2), 7.43(\mathrm{ddd}, J=8.4,6.8,1.0 \mathrm{~Hz}, 1 \mathrm{H}, \mathrm{H}-7), 7.13(\mathrm{~d}, J=2.1 \mathrm{~Hz}, 1 \mathrm{H}, \mathrm{H}-1), 4.50$ $\left(\mathrm{s}, 3 \mathrm{H}, \mathrm{CH}_{3}\right) ; \delta_{\mathrm{C}}\left(\mathrm{DMSO}-d_{6}\right): 143.9,140.9,133.7,132.5,131.9,129.6,123.7,123.2,121.5$, 120.3, 100.4, 41.3; HRMS (ESI) for $\mathrm{C}_{12} \mathrm{H}_{11} \mathrm{~N}_{2}[\mathrm{M}+\mathrm{H}]^{+}$: calcd 183.0922, found 183.0925.

\section{Acknowledgements}

Gitte Van Baelen would like to thank the IWT-Flanders (The Institute for the promotion of Innovation by Science and Technology in Flanders) for a PhD scholarship and Philippe Franck for the technical assistance. The authors acknowledge financial support from the University of Antwerp (GOA BOF UA, NOI BOF UA) and the Flemish Government (Impulsfinanciering van de Vlaamse Overheid voor Strategisch Basisonderzoek PFEU 2003). 


\section{References}

1. Website of the World Health Organization: http://www.who.int/en/

2. (a) Cimanga, K.; De Bruyne, T.; Lasure, A.; Van Poel, B.; Pieters, L.; Claeys, M.; Vanden Berghe, D.; Kambu, K.; Tona, L.; Vlietinck, A. J. Planta Med. 1996, 62, 22. (b) Cimanga, K.; De Bruyne, T.; Pieters, L.; Claeys, M.; Vlietinck, A. Tetrahedron Lett. 1996, 37, 1703. (c) Cimanga, K.; De Bruyne, T.; Pieters, L.; Vlietinck, A.; Turger, C. A. J. Nat. Prod. 1997, 60, 688. (d) Pousset, J. - L.; Martin, M. - T.; Jossang, A.; Bodo, B. Phytochemistry 1995, 39, 735. (e) Sharaf, M. H. M.; Schiff, P. L., Jr.; Tackie, A. N.; Phoebe, C. H., Jr.; Martin, G. E. J. Heterocycl. Chem. 1996, 33, 239.

3. Hostyn, S.; Maes, B. U. W.; Pieters, L.; Lemière, G. L. F.; Mátyus, P.; Hajós, G.; Dommisse, R. A. Tetrahedron 2005, 61, 1571.

4. Hostyn, S.; Maes, B. U. W.; Van Baelen, G.; Gulevskaya, A.; Meyers, C.; Smits, K. Tetrahedron 2006, 62, 4676.

5. Van Miert, S.; Hostyn, S.; Maes, B. U. W.; Cimanga, K.; Brun, R.; Kaiser, M.; Mátyus, P.; Dommisse, R.; Lemière, G.; Vlietinck, A.; Pieters, L. J. Nat. Prod. 2005, 68, 674.

6. Van Baelen, G.; Meyers, C.; Lemière, G. L. F.; Hostyn, S.; Dommisse, R.; Maes, L.; Augustyns, K.; Haemers, A.; Pieters, L.; Maes, B. U. W. Tetrahedron, 2008, 64, 11802.

7. Arzel, E.; Rocca, P.; Grellier, P.; Labaeïd, M.; Frappier, F.; Guéritte, F.; Gaspard, C.; Marsais, F.; Godard, A.; Quéguiner, G. J. Med. Chem. 2001, 44, 949.

8. For the synthesis of A-ring stripped substituted neocryptolepines see: Hostyn, S.; Van Baelen, G.; Lemière, G. L. F.; Maes, B. U. W. Adv. Synth. Catal., 2008, 350, 2653.

9. (a) Popowycz, F.; Mérour, J.-Y.; Joseph, B. Tetrahedron 2007, 63, 8689. (b) Gribble, G. W. J. Chem. Soc., Perkin Trans. 1 2000, 1045. (c) Humphrey, G. R.; Kuethe, J. T. Chem. Rev. 2006, 106, 2875. (d) Song, J. J.; Reeves, J. T.; Gallou, F.; Tan, Z.; Yee, N. K.; Senanayake, C. H. Chem. Soc. Rev. 2007, 36, 1120.

10. (a) Jia, Y.; Zhu, J. J. Org. Chem. 2006, 71, 7826. (b) Nazaré, M.; Schneider, C.; Lindenschmidt, A.; Will, D. W. Angew. Chem. Int. Ed. 2004, 43, 4526. (c) Gribble, G. W. In Palladium in Heterocyclic Chemistry; Li J. J.; Gribble, G. W. Eds.; Elsevier: Oxford, 2007; Vol. 26, p 145.

11. Das, B.; Venkateswarlu, K.; Majhi, A.; Siddaiah, V.; Reddy, K. R. J. Mol. Catal. A: Chem. 2007, 267, 30 . 